\title{
ON THE BIOLOGY OF THE CAPRELLIDAE. GROWTH AND MOULTING OF PSEUDO- PROTELLA PHASMA MONTAGU
}

\author{
By R. J. Harrison \\ Gonville and Caius College, Cambridge
}

(Text-figs. I-6)

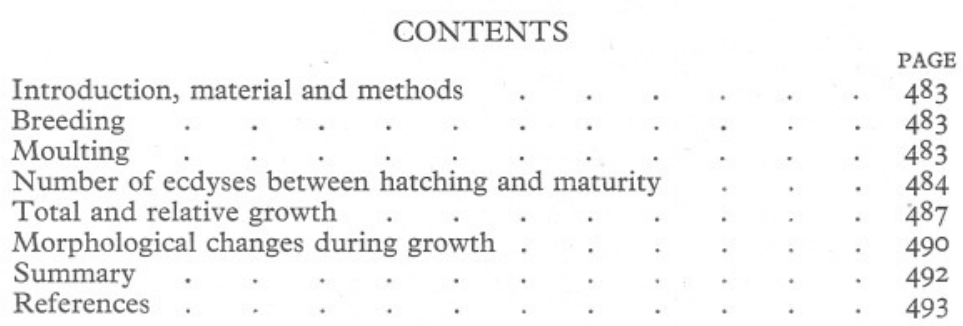

Introduction, Material AND Methods

This study of the growth of one species of caprellid was undertaken to see if an aberrant type of amphipod grew in a manner similar to the normal (Sexton, I924; Le Roux, 1933). Pseudoprotella phasma Montagu var. typica (Chevreux \& Fage, I925) was selected, since this is the commonest caprellid found in the Plymouth region. The animals examined were collected at intervals during I939 in Plymouth Sound on hydroids (mainly Antennularia spp.) at a depth of 6-Io fathoms. Many animals were kept in the laboratory and their moults were collected. Individual specimens were used for the measurements and drawings. These were checked against the moults except in the case of the young, where the moults were too delicate to be preserved. Individuals kept in the laboratory for several instars reproduced the measurements of the same instars straight from the sea. The measurements were made with a microscope with a calibrated micrometer eyepiece and a camera lucida was used for the drawings.

\section{BREEDING}

Pseudoprotelia breeds only in the spring and summer months. The young hatched at this time themselves breed the following year. The number of young in the brood varies between twenty and forty. Since ovigerous females of various sizes are found it is evident that two or more broods may occur in the life cycle. The largest growth stages are only found in any abundance in the summer months, while in the winter months only animals of intermediate unsexed stages are found. Copulation has not been observed.

\section{Moulting}

The process of moulting in Pseudoprotella phasma is similar to that described in Gammarus chevreuxi by Sexton (1924). Moulting nearly always takes place 
at night and an animal about to moult can be recognized many hours before ecdysis by its sluggishness and its refusal to accept food. The animal first bends itself double with a series of convulsive jerks, as if to loosen the skin. The cuticle splits on the dorsal surface just behind the head. The anterior portion is then pulled off forwards by the second pair of chelae. The animal next grasps a branch of the hydroid and kicks violently until the rest of the skin is thrown off. If this fails, it hooks the loose skin round a branch of the hydroid and attempts to crawl out, hauling itself up on neighbouring branches by its chelae. The whole process is accomplished in a remarkably short space of time; in one ecdysis moulting was completed in under $5 \mathrm{~min}$. The process must be completed rapidly, for the animal quickly swells to the next moult size. Exhausted animals are often found in the morning with the posterior part of the skin still attached to them, struggling to throw it off. After the moult the animal is very sensitive, and the least movement causes it to jump into the "ready" position (Bereitschaftstellung, Wetzel, 1932). Animals that have just moulted can be thus recognized by breaking the surface film of the water in the bowl, or even by slamming the door. They do not eat the cast skin and I have not observed one animal helping another to remove it (see moulting in Gammarus chevreuxi, Sexton, 1924). Individuals of the later instars occasionally experience difficulty in moulting. Antennae and gills may be torn off during the moult.

\section{Number of ECDYSES BetWeEn Hatching AND Maturity}

Sixteen instars of Pseudoprotella phasma were found, which could be placed into their respective instars by visual examination. Until instar XII both sexes are alike. After this stage the females can be differentiated from the males by their developing a brood pouch. It is uncertain at which point sexual maturity is reached.

The length of the body, the length of the flagellum and the lengths of the basal segments of the antenna, the length and breadth of the second pair of chelae and the length of the third somite lend themselves admirably to accurate measurement. These data enable a particular animal to be placed in its instar at once, and for rough purposes the number of segments in the flagellum may be counted. The measurements were reproducible to within $\pm 5 \%$ and such variations occurred mostly in the larger growth sizes. Table I gives the measure-

\section{TABLE I}

\begin{tabular}{|c|c|c|c|}
\hline \multicolumn{2}{|c|}{ Growth stage XIV } & \multicolumn{2}{|c|}{ Growth stage XVII } \\
\hline Length & & Length & \\
\hline of chela & Number of & of chela & Number of \\
\hline $\begin{array}{c}\text { in } \mathrm{mm} \text {. } \\
2 \cdot \mathrm{I} 5\end{array}$ & 2 & $\begin{array}{l}\text { in } \mathrm{mm} \text {. } \\
3.98\end{array}$ & 2 \\
\hline $2 \cdot 17$ & IO & $4 \cdot 08$ & IO \\
\hline $2 \cdot 19$ & I5 & $4 \cdot 18$ & I3 \\
\hline $2 \cdot 2 \mathrm{I}$ & IO & $4 \cdot 28$ & I 2 \\
\hline $2 \cdot 23$ & 3 & $4 \cdot 38$ & 3 \\
\hline
\end{tabular}


ments of the length of the second chela in two growth stages (XIV and XVII). Forty specimens belonging to each stage were measured.

The length of the chela of stage XIII is $\mathrm{I} \cdot 60 \mathrm{~mm}$., that of stage XV is $2.60 \mathrm{~mm}$. and that of stage XVI is $3.30 \mathrm{~mm}$. Since measurements of other parts show as little variation as those shown in Table I for the chela it can be seen that little difficulty is experienced in placing an animal in its instar by measurement, there being no overlap.

Table II gives the measurements of the body and other parts in millimetres. In nearly all cases twenty to fifty animals were measured; where only a few

TABLE II

All measurements in millimetres Antennae

\begin{tabular}{|c|c|c|c|c|c|c|c|}
\hline \multirow{2}{*}{$\begin{array}{l}\text { Growth } \\
\text { stage }\end{array}$} & \multicolumn{2}{|c|}{ Chelae } & \multirow{2}{*}{$\begin{array}{l}\text { Length } \\
\text { first } \\
\text { segment }\end{array}$} & \multirow{2}{*}{$\begin{array}{l}\text { Total } \\
\text { length }\end{array}$} & \multirow{2}{*}{$\begin{array}{l}\text { Third } \\
\text { somite }\end{array}$} & \multirow{2}{*}{$\begin{array}{l}\text { Body } \\
\text { length }\end{array}$} & \multirow{2}{*}{$\begin{array}{r}\text { Przibran } \\
\text { constan }\end{array}$} \\
\hline & Length & Breadth & & & & & \\
\hline \multicolumn{8}{|c|}{ UNSEXED } \\
\hline I & 0.20 & 0.10 & 0.13 & 0.89 & 0.13 & $I \cdot I 7$ & $\cdots$ \\
\hline II & 0.22 & 0.10 & 0.18 & 0.89 & 0.16 & I. 35 & $I \cdot I 3$ \\
\hline III & $\cdots$ & . & . & . & . & $\cdots$ & . \\
\hline IV & 0.32 & 0.16 & 0.22 & I. 40 & 0.23 & $I \cdot 90$ & . \\
\hline $\mathrm{V}$ & 0.38 & 0.18 & 0.25 & 2.09 & 0.28 & $2 \cdot 18$ & $I \cdot I 2$ \\
\hline VI & 0.44 & 0.19 & 0.30 & $2 \cdot 29$ & 0.33 & 2.57 & $\mathrm{I} \cdot \mathrm{I} 7$ \\
\hline VII & 0.60 & 0.25 & 0.35 & $2 \cdot 70$ & $0.4 \mathrm{I}$ & 3.00 & $I \cdot I 6$ \\
\hline VIII & 0.70 & 0.26 & 0.40 & 2.99 & 0.53 & 3.50 & $\mathrm{I} \cdot \mathrm{I} 7$ \\
\hline IX & 0.84 & 0.32 & 0.50 & $3 \cdot 32$ & 0.60 & $4 \cdot \mathrm{IO}$ & $I \cdot 20$ \\
\hline $\mathrm{X}$ & I.OO & 0.46 & 0.60 & 3.71 & 0.77 & 4.95 & $I \cdot I 9$ \\
\hline XI & $I \cdot 20$ & 0.50 & 0.70 & $5 \cdot 10$ & 0.82 & $5 \cdot 70$ & $I \cdot I 4$ \\
\hline XII & $I \cdot 35$ & 0.55 & 0.80 & 5.95 & 0.94 & $6 \cdot 40$ & $I \cdot I 2$ \\
\hline \multicolumn{8}{|c|}{ MALE } \\
\hline XIII & $I .60$ & 0.60 & 0.90 & $6 \cdot 55$ & $I \cdot I 2$ & $7 \cdot 80$ & $I \cdot 2 I$ \\
\hline XIV & $2 \cdot 20$ & 0.78 & $I \cdot 20$ & 7.85 & $I \cdot 50$ & 8.80 & I. I3 \\
\hline XV & $2 \cdot 60$ & 0.85 & $\mathrm{I} \cdot 30$ & 8.95 & $I \cdot 72$ & 10.4 & $\mathrm{I} \cdot \mathrm{I} 8$ \\
\hline XVI & $3 \cdot 30$ & $I \cdot O O$ & $I \cdot 60$ & II 5 & $2 \cdot 10$ & $12 \cdot 6$ & $I \cdot 20$ \\
\hline XVII & $4 \cdot 20$ & $\mathrm{I} \cdot 30$ & $I \cdot 90$ & $14 \cdot 4$ & 2.65 & $\mathrm{I} 4 \cdot 4$ & $I \cdot I 3$ \\
\hline \multicolumn{8}{|c|}{ Female } \\
\hline XIII & $I \cdot 60(4)$ & 0.70 (4) & $0.90(5)$ & $6.45(5)$ & I. IO (9) & $7 \cdot 40(9)$ & $I \cdot I O$ \\
\hline XIV & 2.05 (I5) & 0.90 (15) & I. IO (I5) & $7 \cdot 50$ (15) & I. 44 (I5) & 8.60 (I5) & $I \cdot I 4$ \\
\hline XV & 2.50 & 0.95 & $I \cdot 40$ & 9.90 & $I .69$ & 9.80 & $I \cdot I 4$ \\
\hline XVI & 3.00 & $I \cdot 00$ & $I \cdot 50$ & $10 \cdot 2$ & $2.0 \mathrm{I}$ & II $\cdot 5$ & $\mathrm{I} \cdot \mathrm{I7}$ \\
\hline XVII & 3.80 & I.05 & $I \cdot 60$ & I 2.0 & $2 \cdot 40$ & 13.0 & $I \cdot I 3$ \\
\hline
\end{tabular}

specimens were available their number is indicated in brackets by the measurement.

If the logarithms of the lengths obtained from the sixteen known growth stages be plotted against the instar number a straight line is obtained (Fig. I). It will be seen that the third stage is missing. When kept in the laboratory the mother lifts the young out of her brood sac with her first pair of chelae and places them upon her antennae and second pair of chelae where they feed on her food (Montagu, I802). The young live in this manner for about three weeks, then one by one they fall off and sink to the bottom of the bowl. Attempts to rear the young beyond this stage have failed. Both the young obtained from the laboratory broods and young so far found attached to 
females taken from the sea have never been larger than stage II. The smallest animals found in the sea free-living on the hydroids have been stage IV. It would appear that the young either jump stage III and moult straight from stage II to stage IV or that there may be a change in the mode of living. Stage III has not been obtained by fine tow nets, netting dragged over the hydroid bed or by dredging.

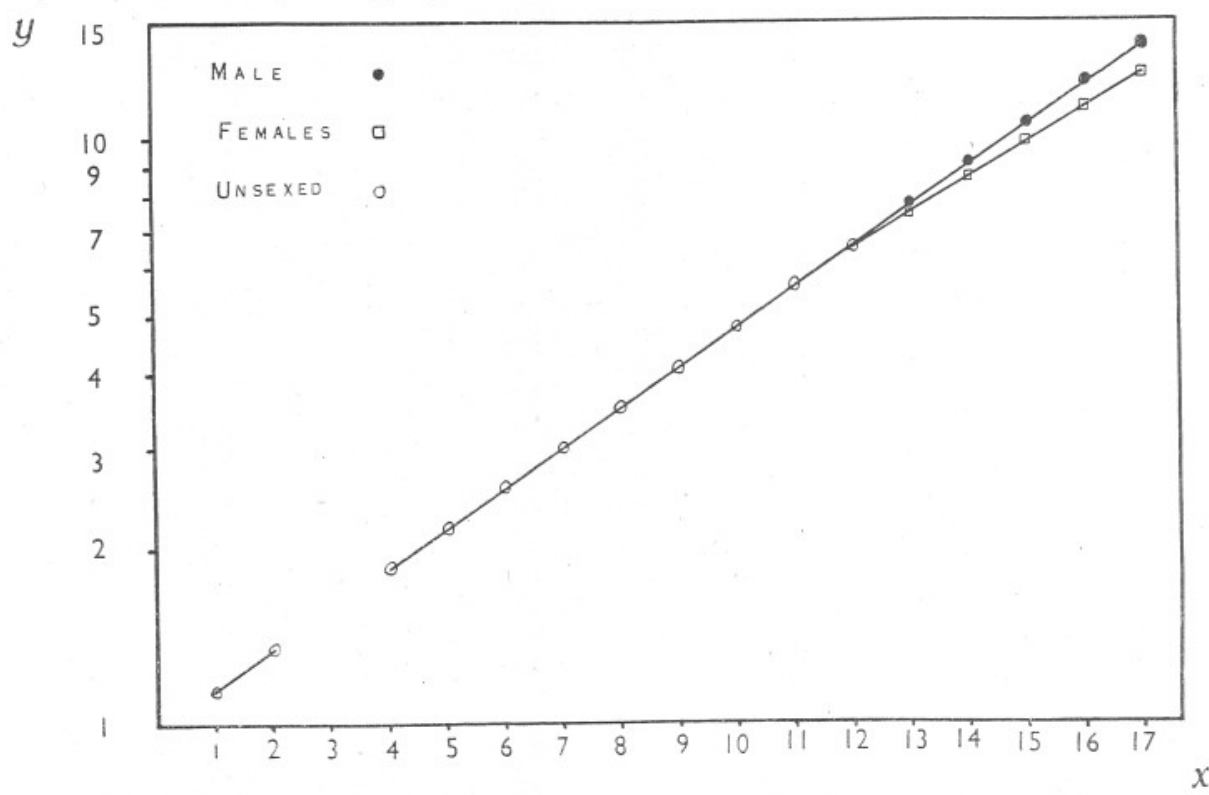

Fig. I. Logarithms of body lengths $(y)$ as a function of the growth stage $(x)$.

It will be seen (Fig. I) that the logarithm of the length of the $(n+\mathrm{I})$ th stage differs from that of the $(n)$ th stage by 0.068 . Or

From this

$$
\begin{gathered}
\log L_{n+1}-\log L_{n}=0.068 . \\
\frac{L_{n+1}}{L_{n}}=\mathrm{I} \cdot \mathrm{I} 69 .
\end{gathered}
$$

The figure $I \cdot I 69$ is the common ratio of the geometric series obtained from the body lengths and is known as the Przibram quotient, see Table II, (Przibram, I93I). By a coincidence the length of the first stage is $\mathrm{I} \cdot \mathrm{I} 7 \mathrm{~mm}$.; so that the approximate length in millimetres of any specimen of Pseudoprotella phasma found in Plymouth Sound can be determined, knowing its growth stage, by means of the following equation:

$$
y=\mathrm{I} \cdot 169^{n},
$$

where $y$ is the length of the $n$th stage measured in millimetres. For the females from the twelfth stage onwards the equation differs slightly from this:

where

$$
\begin{gathered}
y=6.5 \mathrm{I} \times \mathrm{I} \cdot 48^{n-12}, \\
6.5 \mathrm{I}=\mathrm{I} \cdot \mathrm{I} 69^{12} .
\end{gathered}
$$


For any different scale of measurement a correcting constant $k$ must be introduced.

If the logarithm of the length of the growth stage be plotted against the logarithm of the length of a part or an appendage straight lines are obtained. These graphs fit the simple allometry equations,

$$
y=b x^{a},
$$

where $y$ is the length of the part or appendage and $x$ the length of the body, $b$ a constant depending on the unit of measurement and $a$ the constante de croissance (Teissier, I937) or the constant differential growth ratio (Huxley, I932). This equation has been criticized in that it is not dimensionally equivalent (Needham, I934). But it must be realized that the term length of an instar or appendage is not an absolute mathematical dimension but the visible result of many complex internal processes producing growth. The equation formulated above is that which best fits the practical results and it must not be considered as a basic formula of growth. If the formula is written

$$
\frac{y}{y_{0}}=b\left(\frac{x}{x_{0}}\right)^{a},
$$

the criticism can no longer be made, for both sides of the equation are dimensionless. For a further mathematical treatment of the equation see Lumer (I939).

\section{Total and Relative Growth}

Table II and Fig. I show that after stage XII the length of the body and appendages are shorter in the females than in the males of the same instar. The constant $a$ obtained by $\log y / \log x$ indicates the ratio of the rate of growth of a part or appendage to the rate of growth of the body. If the value of the constant is $<\mathrm{I}$ the body is increasing in length faster than the part. If the constant is > I the part is increasing in length faster than the body, while if the constant $=\mathrm{I}$ the growth rates are equal and growth is isometric.

Table III a gives the constants for the parts measured in the unsexed, male and female animals. The constant for the third somite remains unaltered throughout the life of both sexes (Fig. 2B), while in other parts the value changes after stage XII. Table III B shows the constants recalculated relative to the third somite constant to enable the relative growth rate changes to be understood more easily.

\section{TABLE III A}

Values of the constant $a=\log y / \log x$, where $x$ is the body length and $y$ is the length of the part.

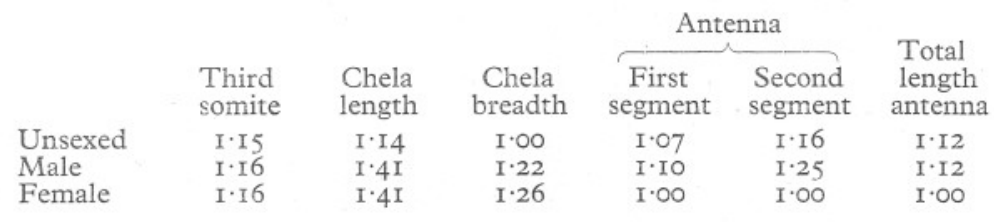




\section{TABLE IIIB}

Values of the constant $a$ relative to the third somite constant.

\begin{tabular}{|c|c|c|c|c|c|c|}
\hline & \multirow[b]{2}{*}{$\begin{array}{l}\text { Third } \\
\text { somite }\end{array}$} & \multirow[b]{2}{*}{$\begin{array}{l}\text { Chela } \\
\text { length }\end{array}$} & \multirow[b]{2}{*}{$\begin{array}{c}\text { Chela } \\
\text { breadth }\end{array}$} & \multicolumn{2}{|c|}{ Antenna } & \multirow{2}{*}{$\begin{array}{c}\text { Total } \\
\text { length } \\
\text { antenna }\end{array}$} \\
\hline & & & & $\begin{array}{l}\text { First } \\
\text { segment }\end{array}$ & $\begin{array}{l}\text { Second } \\
\text { segment }\end{array}$ & \\
\hline Unsexed & I. 00 & $I \cdot 00$ & 0.87 & 0.93 & I.०O & 0.90 \\
\hline Male & $I \cdot 00$ & $I \cdot 22$ & I.06 & 0.95 & I.O9 & 0.90 \\
\hline Female & $1 \cdot 00$ & $I \cdot 22$ & $I \cdot 09$ & 0.87 & 0.87 & 0.87 \\
\hline
\end{tabular}

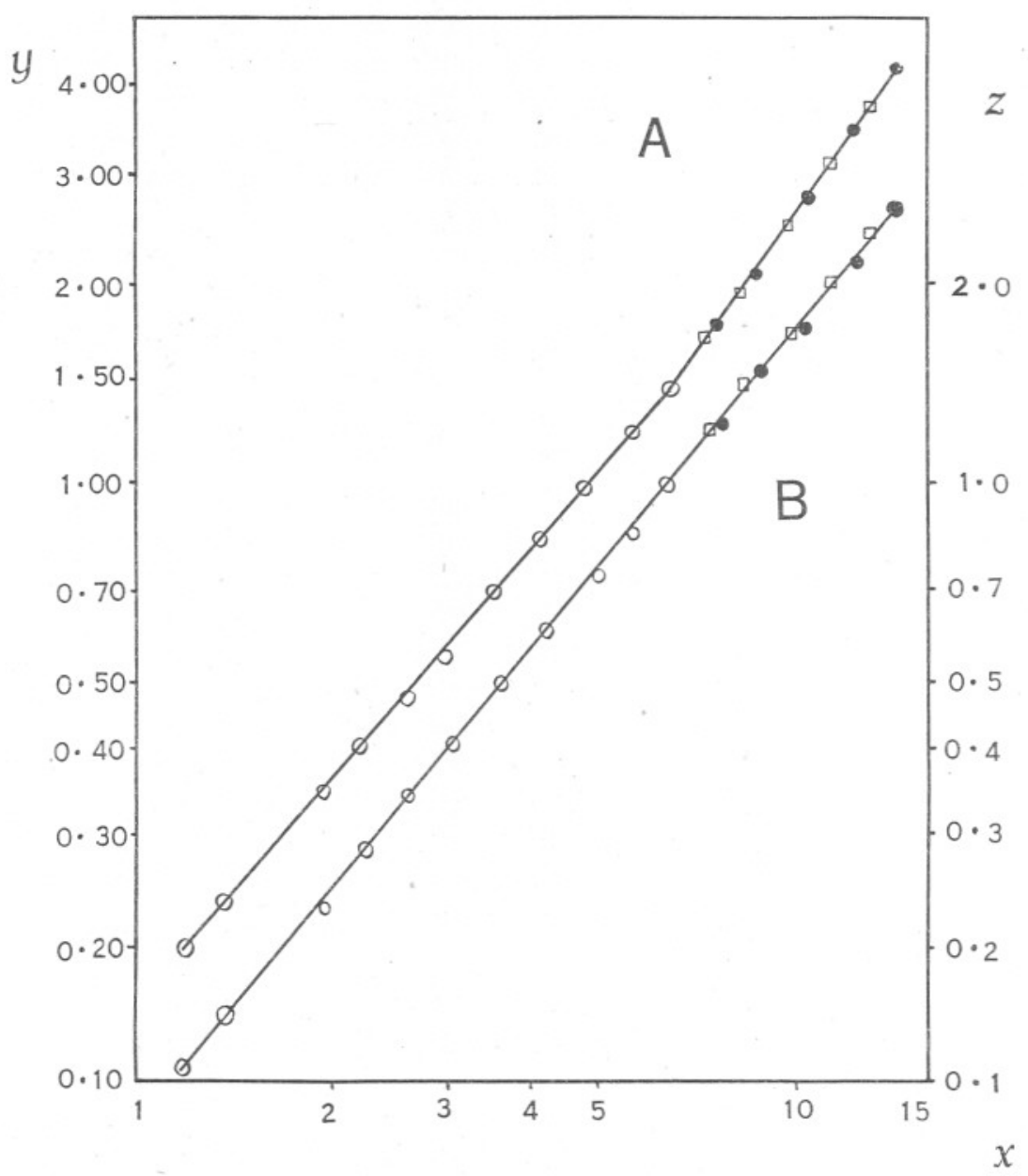

IFig. 2. A, The logarithm of the length of the second chela $(y)$ against the logarithm of the body length $(x)$. B, The logarithm of the length of the third somite $(z)$ against the logarithm of the body length $(x)$. Males, females and unsexed indicated as in Fig. I. 


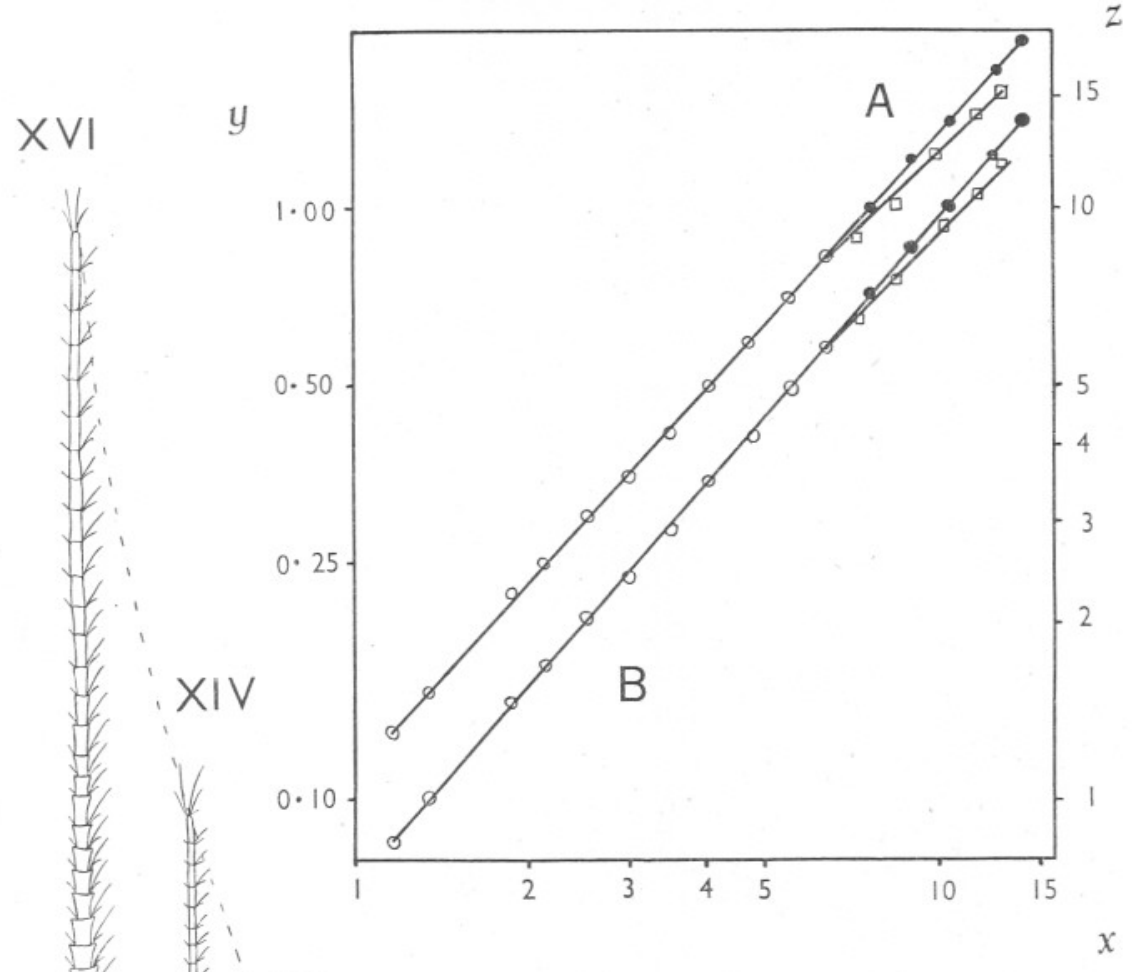

XII

$1 \mathrm{~mm}$

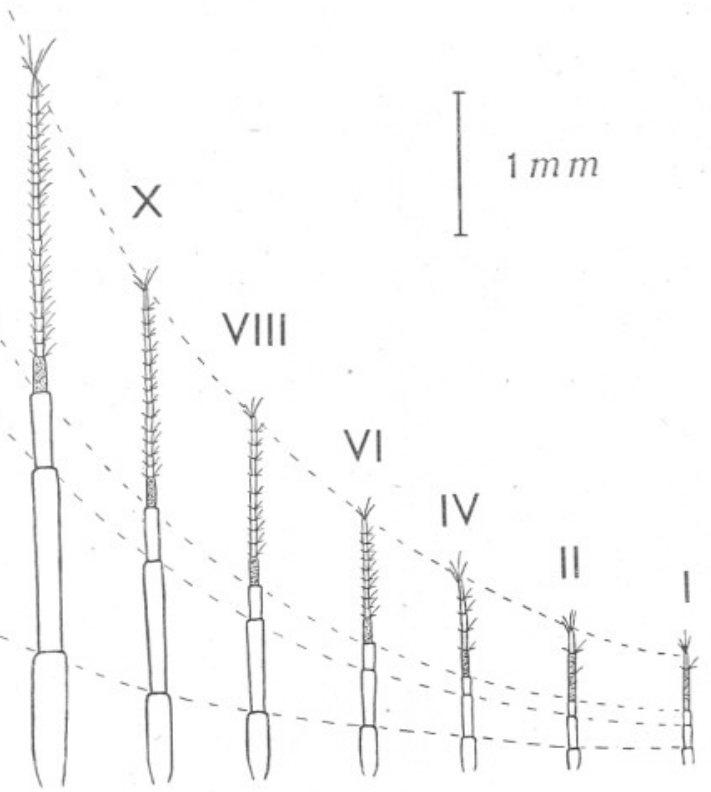

Fig. 3. Camera lucida drawings of nine stages in the growth of the antennae; the region of growth of the flagellum is shaded. The graph shows A the logarithm of the length of the first antennal segment $(y)$ against the logarithm of the body length $(x)$. B, The logarithm of the length of the whole antenna $(z)$ against the logarithm of the body length $(x)$. Males, females and unsexed indicated as in Fig. I. 
In the male both the chelae (Fig, $2 \mathrm{~A}$ ) and the antennae (Fig. $3 \mathrm{~A}, \mathrm{~B}$ ) increase in relative growth rate after stage XII. In the female the chelae increase in growth rate and at a similar rate as the increase in the growth rate of the male chelae. But the growth rate of the antennae in the female is less than that of the antennae in the unsexed animals and is the same as the growth rate of the body, so growth is isometric (Table IIIA).

\section{Changes IN SHAPE DURING GRowTH}

Such slight morphological changes as occur during development are confined to the chelae, first antennae, and body spines.

The first antenna consists of a three-segmented peduncle which remains the same throughout life and a long many-segmented flagellum arising from it. In the first stage the flagellum has two segments, the proximal segment being the region of growth of the flagellum (Fig. 3). In some stages the next segment to be formed may be seen dividing off from the proximal segment. Each segment has a large seta with several hairs at its distal end. The distal segments of the flagellum are long and thin while the proximal segments are short and stout.
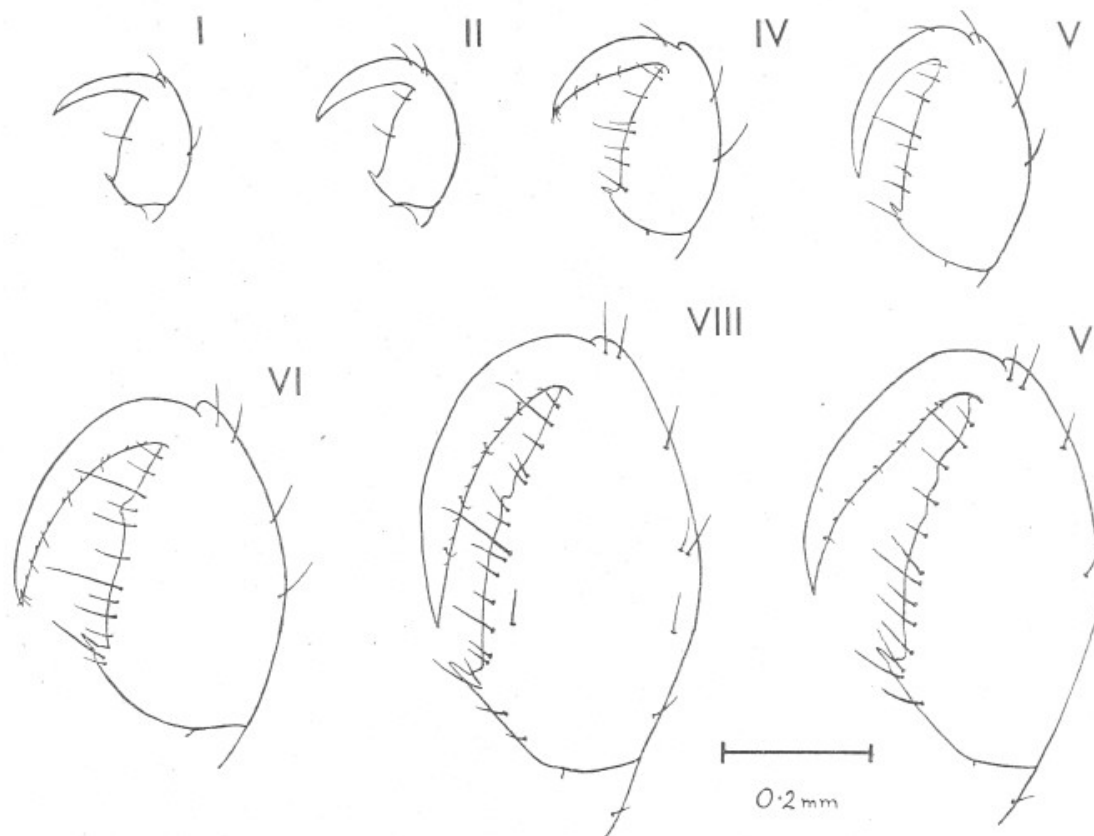

VIII

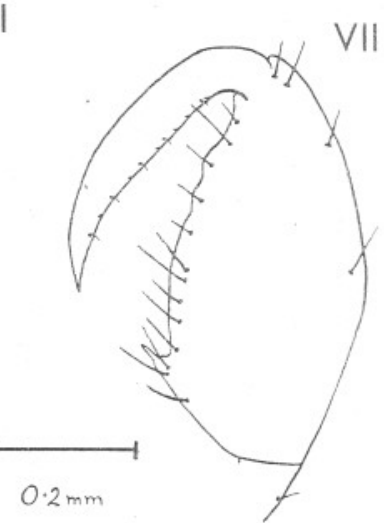

Fig. 4. Camera lucida drawings of the left side of the second left chela of growth stages I-VIII.

As early as stage $\mathrm{V}$ (Figs. 4, 5) the chelae begin to develop indentations on their palmar margins (Sexton, I924, p. 36I). A strong spine is present at the base of the palm. This becomes well developed and strong, helping to secure 


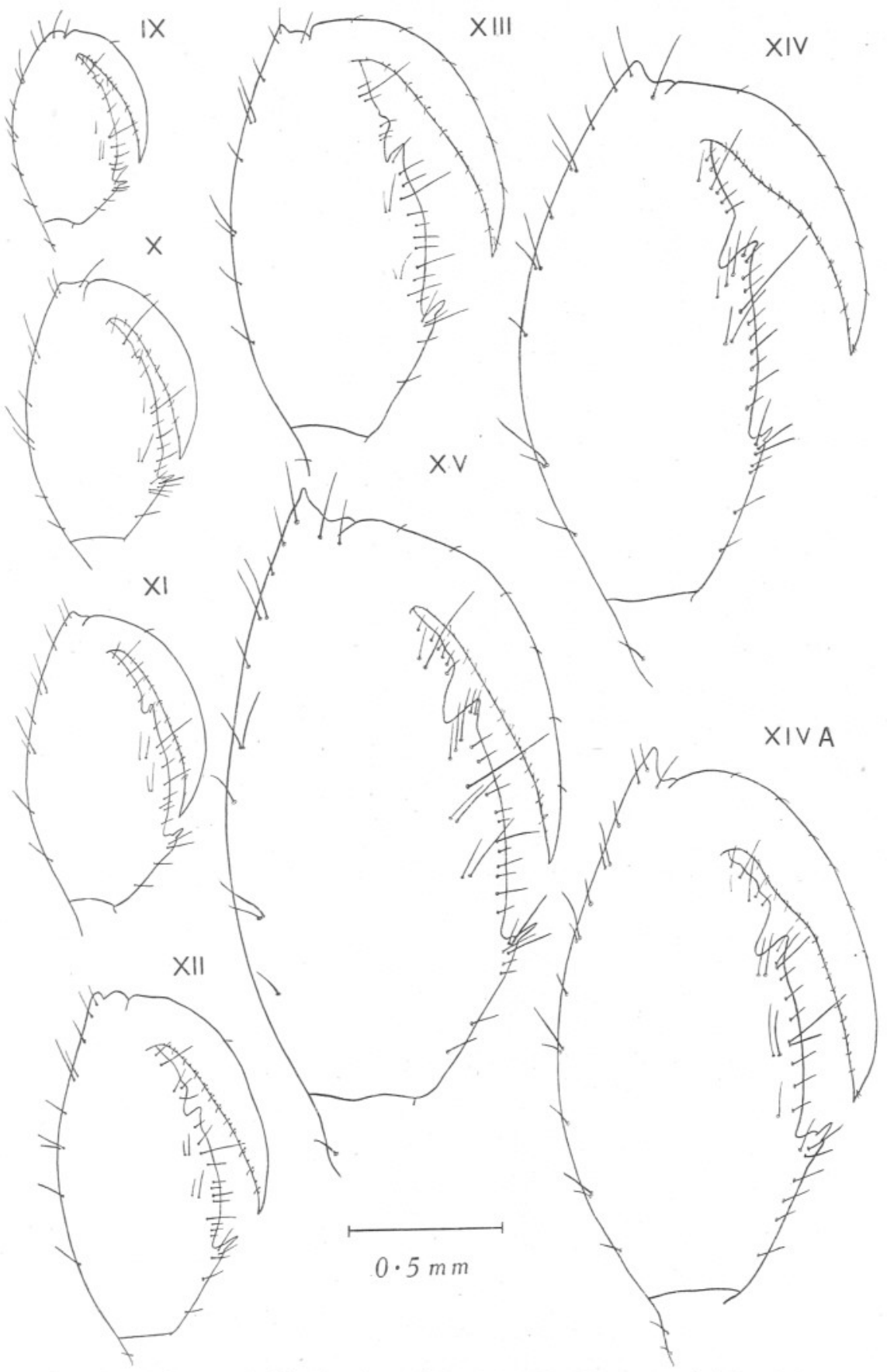

Fig. 5. Camera lucida drawings of the right side of the second right chela of growth stages IX-XV. XIVA is a female of growth stage XIV. 
the grip of the chela on the food. In other caprellids (Haller, I879) it is said to be poisonous and it is true that there is a large-celled gland at its base. Small chitinous thickenings appear on the inner edge of the dactylopodite which increase the cutting power of the joint. The rounded distal end of the palm in the younger stages becomes distinctly pointed in the adult. Hairs arise in a manner similar to the origin of tentacles in medusae. At first two hairs appear some distance apart; at a later ecdysis a third hair appears between the first two and secondary hairs may develop close to the primaries.

From stage $\mathrm{X}$ onwards large spines appear on the dorsal surface of the body
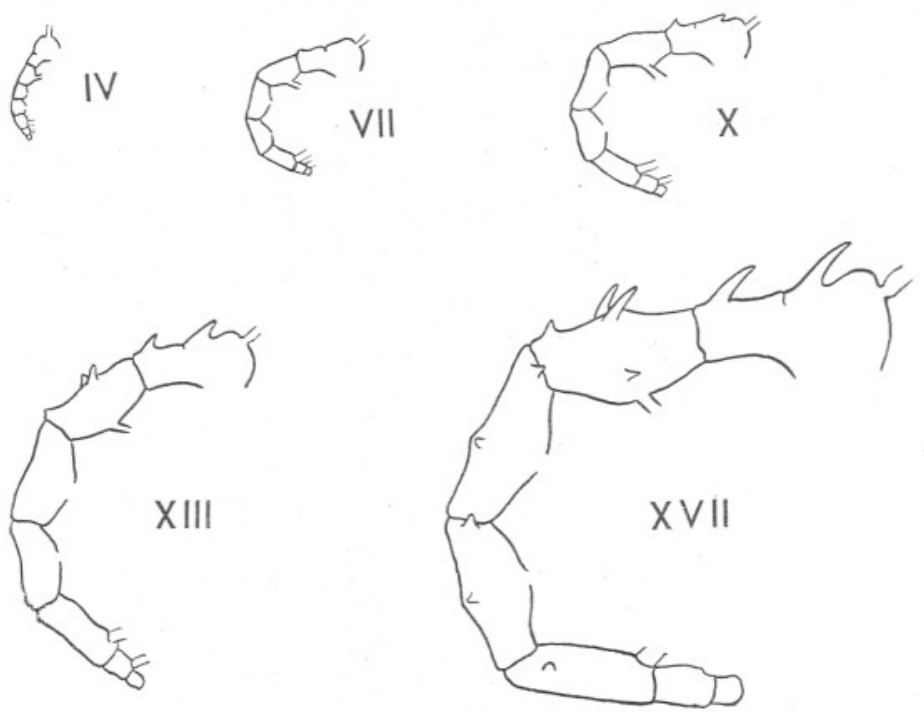

Fig. 6. Camera lucida drawings showing development of body spines in several growth stages. These drawings are not accurately to scale.

(Fig. 6), one on the head, one on the segment fused with the head, two together in the middle of the third segment and another at the posterior end. Other smaller spines and tubercles appear in different positions on the body and are very constant in every stage, both male and female. There are no external morphological differences between the sexes except that the females possess a brood pouch.

My thanks are due to Dr Stanley Kemp, F.R.S., for so kindly giving me every facility to work at the Plymouth Laboratory. I wish also to express my thanks to Mr F. S. Russell, F.R.S., for his great help and advice and to the staff of the Laboratory for collecting and supplying the material.

\section{SUMMARY}

The process of moulting in Pseudoprotella phasma is described. Sixteen instars have been found with a discontinuity in growth at the third stage. The 
instar lengths differ by a common ratio of I.I69 in the male and I.I48 in the female, the animals becoming differentiated at the twelfth stage. There are no secondary sexual characteristics except the brood pouch. The growing parts display simple positive allometry. The growth rates of the chelae and antennae alter after stage XII but remain the same in the third body segment. Changes in shape in the chelae, antennae and spinous armature are described.

\section{REFERENCES}

Chevreux, E. \& Fage, L., I925. Faune de France, 9, Amphipodes, pp. 437-9.

Gosse, P. H., I853. A Naturalist's Rambles on the Devonshire Coast. London.

HAlleR, G., I879. Beitrag zur Kenntnis der Laemodipodes filiformes. Zeitschr. $f$. wiss. Zool., Bd. 33.

Huxley, J. S., I932. Problems of Relative Growth. London.

Le Roux, M.-L., I933. Recherches sur la Sexualité des Gammariens. Sup. Bull. Biol. France Belg., Sup. xvI, pp. I-I38.

Lumer, H., I939. The dimensions and interrelationship of the relative growth constants. Amer. Nat., Vol. LxxirI, No. 747.

Mayer, P., I882. Die Caprelliden des Golfes von Neapel. Fauna u. Flora d. Golf. Néapel, Monogr. 6.

- 1890. Die Caprelliden des Golfes von Neapel. Fauna u. Flora d. Golf. Neapel, Monogr. I7.

Montagu, G., I802. Description of Several Marine Animals found on the South Coast of Devonshire.

Needham, J., I934. Chemical heterogony and the ground plan of animal growth. Biol. Rev., Vol. IX, pp. 79-Io9.

Przibram, H., I93r. Connecting Laws in Animal Morphology. University of London Press.

Sexton, E. W., I924. The moulting and growth stages of Gammarus, with descriptions of the normals and intersexes. Fourn. Mar. Biol. Assoc., Vol. xIII, pp. 340-40I.

Teissier, G., I937. Les Lois Quantitives de la Croissance. Actualités Scientifiques et Industrielles, 455, xI.

Wetzel, A., I932. Studien über die Biologie der Caprelliden. Zeitschr. f. wiss. Zool., Bd. I4I, Heft 3, pp. 347-398. 